\title{
THE ANALYSIS OF INDONESIA'S IMPORTANT ROLE TO KEEP PEACE IN AFGHANISTAN USING A SYSTEM DYNAMIC CONCEPT APPROACH
}

\author{
Arief Rachman ${ }^{1,2}$ \\ 1 Indonesia Defense University, UNHAN Indonesia \\ 2 Ambassador of the Indonesian Embassy in Kabul, Afghanistan
}

\begin{abstract}
Peace in the Central Asia region is a very dynamic situation and changes rapidly from time to time based on the important role of each country in the region. Various conflicts of interest occur in Afghanistan, ranging from the internal conflict in Afghanistan itself and external conflicts involving many countries including the United States, Israel, Russia, and so on. Indonesia, as one of the countries with the largest number of Muslims, also has a major concern for peace in the Central Asia region, especially Afghanistan. This study aims to analyze Indonesia's role in achieving peace in the Central Asia Region, especially in the Afghanistan conflict area. The approach used is the System Dynamic method approach. This method is expected to be able to provide scientific contributions in analyzing Indonesia's role in peace in the Afghanistan region so that it becomes the main basis and consideration in making important decisions and policies towards peace in Afghanistan. The results achieved in this study are several analyzes of the role of Indonesia which is very dynamic based on a systemic concept that produces a dynamic causal loop diagram system that reflects the dynamic efforts by Indonesia to participate in maintaining peace in Afghanistan, under the politics of a free and active Indonesian state.
\end{abstract}

KEYWORDS: Indonesia's Important Role, Peace Afghanistan, System Dynamic Concept Approach.

\section{INTRODUCTION}

President Joko Widodo conveyed Indonesia's stance in fighting terrorism at the Arab American Islamic Summit in Riyadh, Saudi Arabia on May 21, 2017, stating the importance of a religious and cultural approach to tackling terrorism. He stated that weapons and military force alone would not be able to overcome terrorism. Therefore, the Indonesian State balances the hard-power approach with the softpower approach through religious and cultural approaches. During the G20 Summit meeting in Hamburg, Germany, President Joko Widodo again expressed some of his views on dealing with terrorism. He explained the threats that occurred in connection with the occupation of hardline groups in Marawi, Philippines (Sundarakani, 2014).

Delivered by the Minister of Foreign Affairs, the President conveyed the importance of the G20 countries to unite in dealing with such terrorism threats. The President also suggested several things as a solution, including:
"Tightening surveillance and stopping the flow of funding to radical and terrorist groups." $\mathrm{He}$ added, with the information technology capabilities of the G20 member countries, the G20 must be able to become a motor for spreading the value of peace. Regarding the handling of acts of terrorism, Foreign Minister Retno further stated: "President Jokowi reminded that the G20 countries must be able to find solutions to the root of the problem in this issue, which include ending economic inequality and injustice. The G20 must also strengthen cooperation in the intelligence field (Bryson, 1995)

Based on President Joko Widodo's statements at these two international summits, the Indonesian Embassy in Kabul has become a reference for taking steps to fight terrorism and support the Peace Process in Afghanistan. The Indonesian Embassy in Kabul had a meeting with the Afghan peace institution, the High Peace Council, chaired by Karim Khalili. Karim Khalili said that Indonesia has many similar backgrounds with Afghanistan, especially in 
terms of ethnic pluralism and the majority of Islam, and has proven how a country can successfully maintain peace and carry out development. Therefore, Afghanistan would appreciate if Indonesia could share this valuable experience with HPC (High Peace Council) to increase the capacity of HPC in carrying out its duties, through sharing of the best practices in relevant agencies in Indonesia (Herdiawan, 2019).

Besides, the Indonesian Embassy also met with Nahdlatul Ulama Afghanistan on July 8, 2017, to strengthen NUA's (Nahdlatul Ulama Afghanistan) commitment to increasing its role in the Peace Process in Afghanistan by giving full support to the Indonesian Embassy in Kabul. NUA plans to meet with the HPC to conduct friendship to Indonesia, as at the beginning when the HPC and NUA were formed and this delegation will ask the President of the Republic of Indonesia to be able to send a delegation to Afghanistan led by High State Officials under the President for the meeting of the two scholars who inviting all Afghan stakeholders in their role, "Ulama as Messenger of Peace", which in its implementation will join the Afghanistan High Peace Council (HPC).

The Indonesian Embassy in Kabul has also held various meetings with related parties to support the success of the Afghanistan reconciliation process by Indonesia between the Government of Afghanistan, the Ambassadors of neighboring Afghanistan, and also the State of South Korea and Japan UNAMA, NGO ANRSO, academics and youth leaders Afghanistan. The Indonesian Embassy hopes to gather all components of the Afghan stakeholders (HPC) and send them to Indonesia to meet with delegates from the Government, Ulama, and Indonesian youth to share the best practices (Hettne, 2000).

Based on the events or things mentioned above, Indonesia has a concern for the peace of the Afghanistan region which is manifested in an important role of diplomacy, both hard-power and soft-power, in helping to maintain peace in Afghanistan. This paper aims to analyze Indonesia's role in achieving peace in the Central Asia Region, especially in the Afghanistan conflict area. The approach used is the System Dynamic method approach. This method is expected to be able to provide scientific contributions in analyzing Indonesia's role in peace in the Afghanistan region so that it becomes the main basis and consideration in making important decisions and policies towards peace in Afghanistan.

\section{MATERIALS AND METHODS}

\section{II.1. The Concept of Indonesia's Role for Peace in Afghanistan}

Indonesia's position in the Afghanistan Peace Negotiations is as a mediator to seek understanding between the warring parties in Afghanistan. The basis for Indonesia's involvement in the Peace Talks are:

a. An official request from the Government of Afghanistan for the Government of Indonesia to actively participate as a mediator in the Afghanistan Peace Negotiations. During President Ashraf Ghani's visit to Indonesia on April 5, 2017, he said, "Indonesia is a symbol of hope. Indonesia is a symbol of success, a story from a good leader, and a good story in political, cultural, and global leadership. " He also asked the Indonesian President to send a delegation of ministers and scholars to Afghanistan or invite $\mathbf{4 0}$ representatives from groups in Afghanistan to come to Indonesia to see Indonesia's harmony and unity.

b. Indonesia's participation in peace is a Constitutional Mandate set out in the Preamble to the 1945 Constitution, namely "... In the context of realizing world peace based on independence, eternal peace, and social justice".

c. Indonesia's active Free Politics, through the Love of Peace road to Regional Security

d. Indonesia's position as a country with the largest Muslim population and can be accepted as a mediator by the majority of the warring parties as well as other countries in the region and NATO.

e. The history of Indonesia's participation in serving as a mediator for the Peace Talks includes:

1) Indochina Problem Resolution Conference from 15-17 May 1970;

2) Organizing the Jakarta Informal Meeting in 1988-1998 to resolve the Cambodia and Vietnam conflicts; 
3) Mediator of the 2008 Southern Thailand Conflict Peace Negotiations;

4) Mediator of Conflict Peace Negotiations between Thailand and Cambodia in 2011;

5) Mediator of Conflict Peace Negotiations between the Government of the Philippines and the Moro National Liberation Front in 2013

6) Mediator of Conflict Peace Negotiations in Myanmar.

7) Mediator of Conflict Peace Negotiations in Egypt and Tunisia.

f. President Joko Widodo's order to send delegations of Indonesia Sharing the Best Practices to Kabul.

\section{II.2. System Dynamic Approach}

The System Dynamics methodology uses causal relationships in constructing a complex system model. It is the basis for recognizing and understanding the system's dynamic behavior. In other words, the use of system dynamics methodology is more emphasized to the goals of increasing our understanding of how the behavior of the system arises from its structure. Issues that can be appropriately modeled using dynamic methodology are systems that have dynamic properties (changing over time); of its phenomenon structure contains at least one feedback structure (J. W. Forester, 1997).

This paper has many works of literature to support the research, such as System Dynamics Model of Sustainable Urban Development (Chen et al, 2006), A System Dynamic Based DSS for Sustainable Coral Reef Management in Kenting Coastal Zone (Chang et al, 2008), Dynamics of Financial System: A System Dynamics Approach (Nair et al, 2013), Simulation of Dynamics Behaviors for Shipping Equipment Support with System Dynamics Analysis Approach (Jian Hua et al, 2015), Influence of Compensation and Reward on Performance of Employees at Nakuru County Government (Njoroge et al, 2015), A System Dynamics Approach to Food Security through Smallholder Farming (Tsolakis et al, 2017), Establishing the Location of Naval Base Using Fuzzy MCDM and Covering Technique Methods (Okol et al, 2017).

According to Sterman (2000) the principles for creating dynamic models with the characteristics as described above are as follows: a. The desired conditions and actual circumstances must be differentiated in the model.

b. The existence of stock and flow structures in real life must be represented in the model.

c. Different streams conceptually, within the model must be differentiated.

d. Only information that is available to actors within the system should be used in decision modeling.

e. The structure of the rules of decision making within the model should be appropriate (fit) with managerial practices.

f. The Dynamic System model is not created just to provide forecasting or prediction, but furthermore, the dynamic system is intended to understand the characteristics and behavior of internal and external process mechanisms that occur within a particular system.

Dynamic systems are very effective for systems that require good data management. With the flexibility it has, it helps in the process of model formulation, model definition, model validation, policy analysis, and model implementation (Moyano, 2008).

According to Sterman (2000), The use of the System dynamic model is to simulate a policy evaluation, to evaluate the strategic steps taken (ex-post) in generating system performance, as well as for future evaluation (ex-ante) ie alternative steps taken in achieving the objectives.

\section{RESULT AND DISCUSSION}

\section{III.1. Indonesia as a Peace Mediator}

If Indonesia decides to accept the position as "Mediator of Conflict Peace Negotiations in Afghanistan", it will go through the following process:

\section{a. Academic and Ulama Seminar.}

To discuss Indonesia's involvement (Miere, 2014) in the Conflict Peace Negotiation process in Afghanistan, it is necessary to hold an Academic and Ulama Seminar to be able to map the problem of the Afghan Conflict (Indonesian and Afghanistan Ulama Gathering). 
b. Meeting between Indonesian and Afghan Foreign Ministry Officials.

To seek approval from the Government of Afghanistan to the Government of Indonesia. To contact parties who are considered to have an interest in the peace process, including establishing official contacts with the Taliban (there are third parties to bring together the Taliban).

\section{c. Informal Meeting.}

A meeting that will seat the warring parties in Afghanistan at one table without the participation of other countries (Indonesia is willing to facilitate meetings in Jakarta or other designated places).

\section{d. Ceasefire Agreement.}

The meeting will try to establish a ceasefire agreement between the warring parties as long as the peace meeting is held. The parties who will attend the meeting are representatives of the Afghan government, representatives of the Taliban, representatives of the Haqqani Network, and representatives of the High Peace Council (HPC).

\section{e. Afghanistan Peace Process Preliminary Meeting. \\ This meeting will be held to discuss the} points of discussion to be discussed in the peace negotiations and to determine a place for the peace talks to be held. The meeting can be attended by other countries but only acts as an observer.

\section{f. Afghanistan Peace Meeting.}

This meeting will seek common ground for understanding between warring parties in realizing peace in Afghanistan. The meeting will also discuss the fate of militant members after reaching a peace agreement, including their legal status; Full withdrawal of NATO troops from Afghanistan; Election Implementation; and development projects in the long term 10-15 years with the help of the international community (Muhammad, 2014).

\section{g. Signing of the Afghanistan Peace Agreement on Peace.}

The agreement will be signed by the Representative of the Indonesian Government, the President of Afghanistan, and the Main Leader of the Taliban, Main Leader Haqqani, and Leader of the High Peace Council (HPC) Karim Khalili.

\section{h. Afghanistan Peace Agreement talks continue.}

This meeting is a follow-up discussion after peace negotiations with other countries such as Pakistan, India, Iran, countries in the Central Asia region, Saudi Arabia, the United States, the European Union, Russia, China, Australia and South Korea, and Japan, to discuss the assistance they can provide for Afghanistan's restructuring program.

\section{III.2. A System Dynamic Concept Approach For Indonesia's Important Role To Keep Peace In Afghanistan}

Indonesia's important role in peace in Afghanistan is a system dynamic (Sandfort, 1999). Do all components of Afghanistan and the world hope that Indonesia can become a facilitator and mediator of the peace process in Afghanistan. Of course, this will be answered by Indonesia's own willingness to play a role in facilitating and mediating, Peace Building and Peace Making which will be carried out by Indonesia as President Ashraf Ghani hopes for Indonesia, which he conveyed through the Indonesian Minister of Foreign Affairs when visiting Kabul.

The following is a System Dynamic concept in the form of a Causal Loop Diagram which describes the development situation of Indonesia's role in the peace process in Afghanistan as shown in Figure 1. below: 


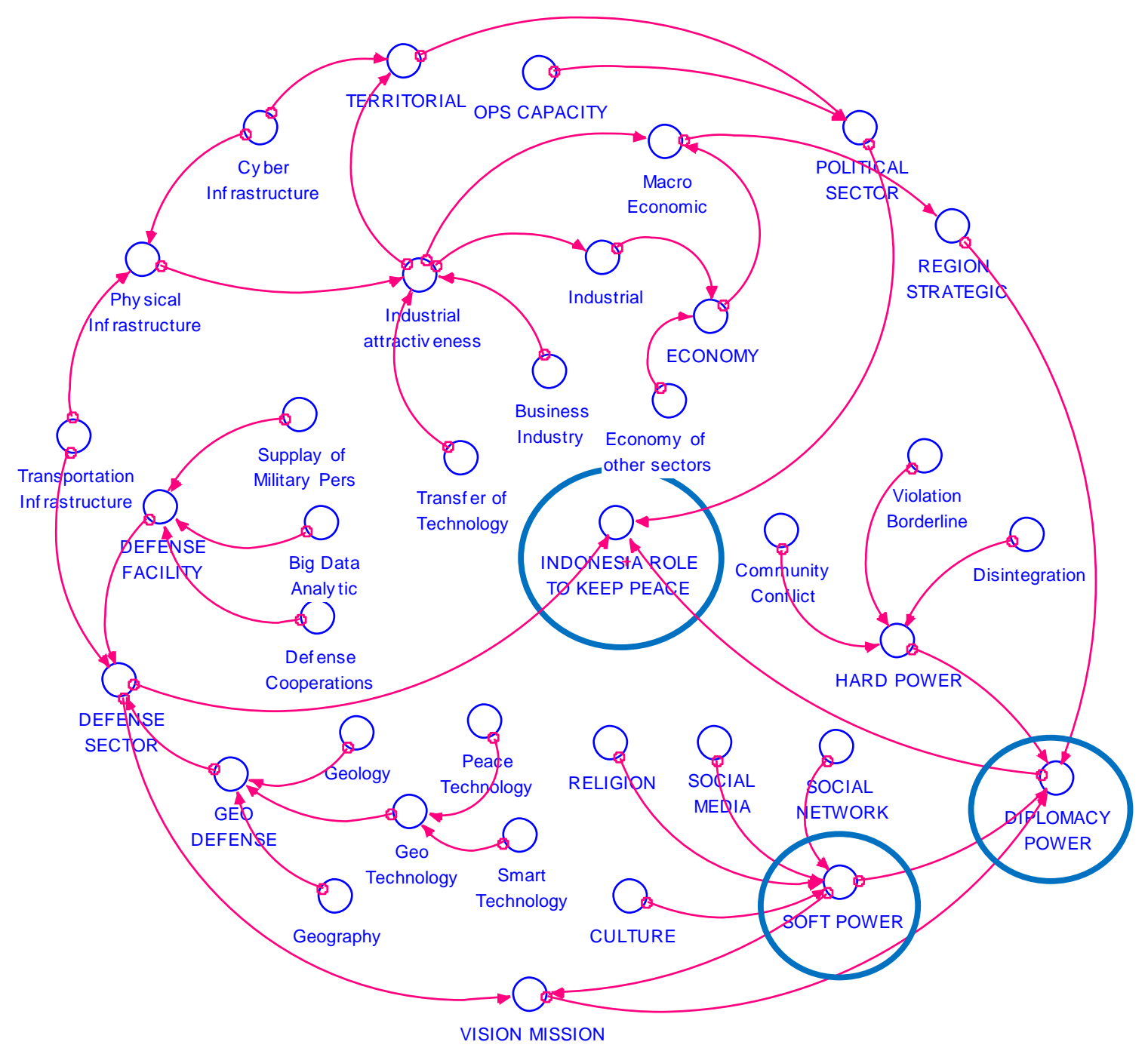

Figure 1. Causal Loop Diagram of Indonesia's Role in the Concept of System Dynamic to Keep Peace in Afghanistan

In Figure 1.Cuasal Loop Diagram of Indonesia's Role in the Concept of System Dynamic to Keep Peace in Afghanistan, it can be explained that Indonesia's important role is a role that is interconnected and interacts between significant variable aspects in the Peace System in the Afghanistan region. This is shown in the concept of a reciprocal diagram of all significant variables which mainly consist of the soft-power diplomacy variable and the hard-power diplomacy variable. The two main variable aspects (Soft \& Hard-Power) and their subvariables are dynamic variables that change all the time depending on cases and the variables are significantly influential (Thornhill, 2009). The advantage of this dynamic system concept is that it can provide an up-to-date and dynamic assessment in terms of aspects, criteria, and timing of the peace process in the Afghanistan region.

The main variables that play a role based on the results of this study are aspects of culture and aspects of religion. These two aspects, both culture and religion, are very influential and significant in the diplomacy process undertaken (Snyder, 2008). The success of peace in the Afghanistan region is a vision and mission that must be achieved and realized properly based on the conditions on the aspects and variables in the System Dynamic model in this study. 


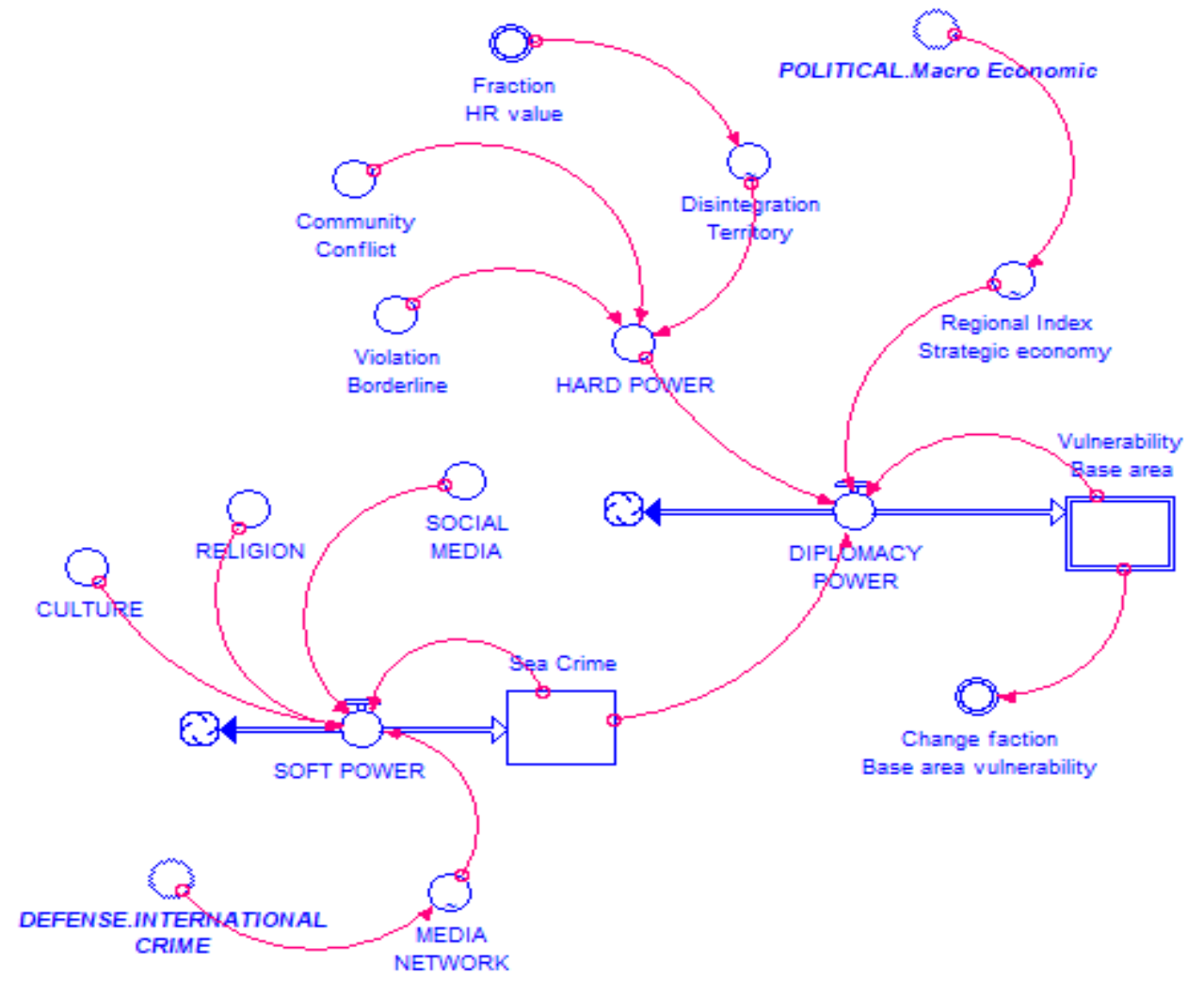

Figure 2. Causal Loop Diagram of Indonesia's Soft-Power Role in the Concept of System Dynamic to Keep Peace in Afghanistan

In Figure 2., it can be explained that several factors that significantly influence Indonesia's Soft-Power Diplomacy are aspects of Religion and Culture. These two aspects are very significant in influencing peace efforts in Afghanistan. The dynamic system formulations that can be formulated in the achievement of diplomacy efforts through the aspects of Culture and Religion are as follows:

\section{FORMULATION OF DIPLOMACY POWER}

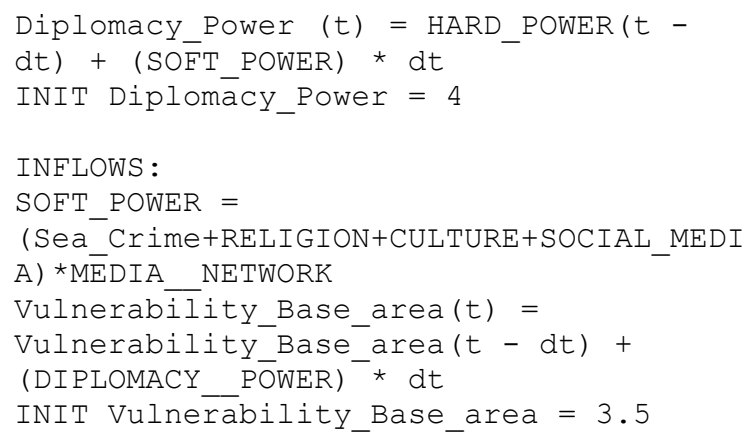

INFLOWS :

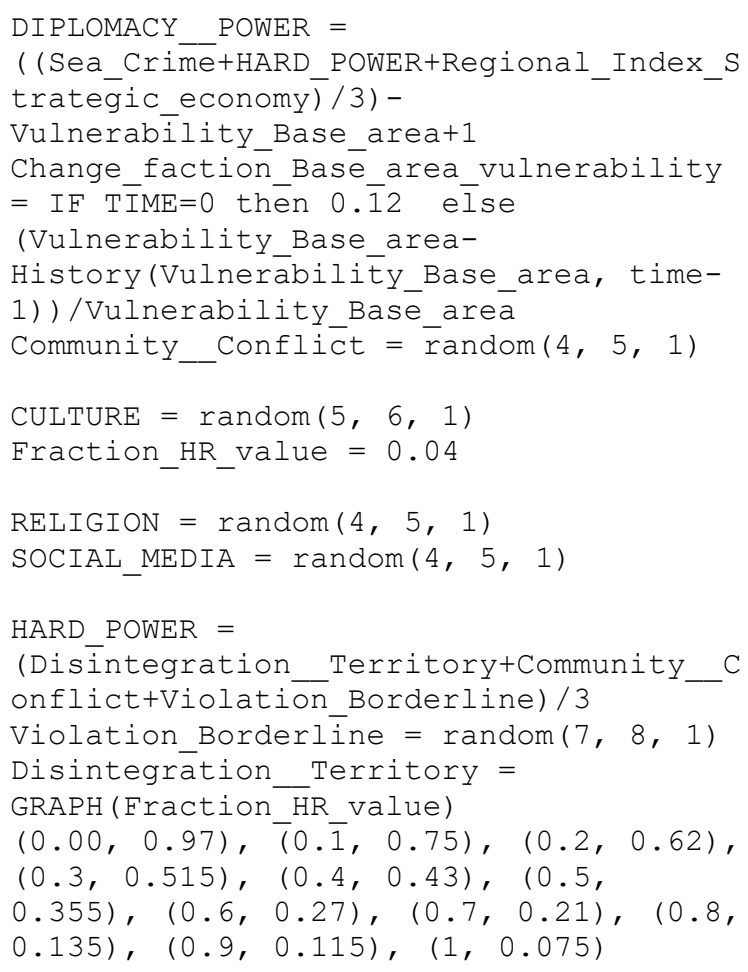




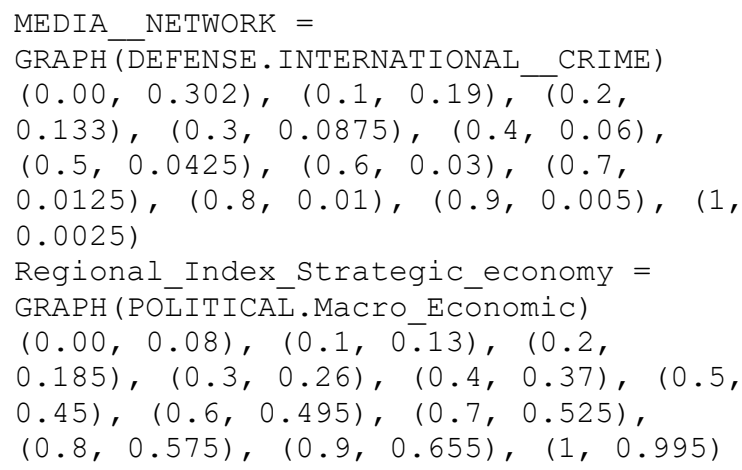

\section{III.3. Soft-Power Diplomacy Response}

Soft-power diplomacy is diplomacy with a cultural and religious approach (Suharyo, 2017). As for the development of "Image Positive" and responses formed both from the response of the media, the response of the public and the response of other organizations in Afghanistan after the soft-power diplomacy by Indonesia in Afghanistan is as follows

\section{a. Media Response}

In general, the Afghan National Media responded very positively and marked by reporting a new process - the creation of a "Peaceful Afghanistan Image".

1) Jessica Donati of the Wall Street Journal. She did not fully believe that Afghanistan could be peaceful immediately but instead, in this worsening condition, there are open opportunities and hopes towards a peace agreement, because all will be ashamed and will increase the costs and victims of the war which will be more massive.

2) Habib Khan Totakhil from the same Media as Jessica said that Indonesia as the largest Islamic country can help Afghanistan "Sharing the Best Practices" in learning moderate Islam.

\section{b. Afghanistan Community Response}

1) Muhammad Naim, an Afghan community leader who is domiciled in Saudi Arabia with a total community of less than 500,000 (five hundred) people, stated that "the people of Afghanistan are optimistic that they will soon unite towards peace if Indonesia's role is active in it. (Towards a Ceasefire Momentum in Kabul Afghanistan, Embassy of The Republic of Indonesia Kabul, Afghanistan, Report Book, Rachman 2018).

2) Muhammad Yusuf, a former Member of Parliament, a community leader from the City of
Hairatan from Balkh Province, which borders three Asian countries, welcomes the role of the Indonesian government in Afghanistan concerning the empowerment of ulama. Hairatan is claimed to be one of the safest cities, both from terrorist attacks and Taliban attacks. Hairatan owns Dry Dock, a Cruid Oil Company that is ready to collaborate with entrepreneurs from Indonesia. They submitted a proposal so that the Jakarta and Surabaya Kadin could become Sister Chamber with Kadin Mazhar-e Sharif so that the atmosphere would be peaceful so that the economic progress of Balkh Province was getting stronger (Ruggi, 1993).

3) Ashmat Ghani, a community leader in Kabul City, said that the people of Afghanistan were looking forward to Indonesia. They could ask them that almost all the people of Afghanistan knew Indonesia. They will certainly accept Indonesia as a mediator compared to their neighboring countries who are also Muslim because they took part in the conflict that Afghanistan is experiencing. The people of Afghanistan do not trust the people of the State of Saudi Arabia because they are also suspected of helping the Taliban (Singh, 2018).

4) Dr. M. Sayyed Yousufzai, an Afghan community leader who lives in Europe and as one of the 2,000,000 (two million), Chairmen of the Afghan Community in Europe said that not only himself but also members of his community are very confident in Indonesia's role in the peace process in Afghanistan will do. This community asks the name Indonesia to become an "Icon" and an Advisor in the process of building a park with an area of 5 hectares so that it can build mosques, libraries, and other meeting buildings and can entrust the names of Indonesian heroes and the Indonesian government to be enshrined as names. in the buildings, they will build. Among them are the name Bung Karno for the park and the name of the Minister of Foreign Affairs Retno Marsudi for the Special Meeting for Women, which will be inaugurated by the President of the Republic of Indonesia. (The Role of Indonesian Ulama In The Process Peace In Afghanistan, Embassy Of The Republic of Indonesia Kabul, Afghanistan, Report Book, Rachman 2018).

5) Abdul Rab Rashad Sayyaf from the Jihad Party said the Taliban's actions were not Jihad and the Taliban were accused of using fake fatwas. Karzai's pro-jihad party also opposed the US bombing and urged to "Withdraw the US 
Security Pact". The Jihad Party has also demanded the withdrawal of US troops from Afghanistan. It is the unclear US presence in Afghanistan that invites other parties to interfere.

c. Responses from Other Organizations

1) UNAMA, said that it is still very concerned about the progress of the security level which has recently been getting worse. (Indonesia's Important Role Keeping Peace In Afghanistan, Embassy of The Republic of Indonesia Kabul, Afghanistan, Report Book., Rachman, 2017). UNAMA's efforts through the European Government have taken the right steps for carrying out Anti-Corruption efforts in Government. This is the right step to be able to prepare a "Good Governance" Government so that all "stakeholders" in Afghanistan can give "trust" to the Government so that opportunities for reconciliation will be more open in the future.

2) The Agha Khan Development Network (AKDN) is one of the NGOs working in Afghanistan that has been active in the fields of Education, Health, Development of Disadvantaged Areas, Community Communities, and the International Scholarship Program for more than 50 years. to assist the People and Government of Afghanistan. This remark was conveyed by Ambassador AKDN H.E. Nurjehan Mawani while attending an activity at the Russian Embassy last Sunday (07/05). He strongly supported the Republic of Indonesia's participation by establishing the Indonesian Islamic Center (IIC) and plans to build a Hospital, Guest House, and Library. AKDN is ready to help and work together to support the implementation of the project. (Indonesia's Important Role Keeping Peace In Afghanistan, Embassy of The Republic of Indonesia Kabul, Afghanistan, Report Book., Rachman, 2017)

3) Asia Foundation through Claire Anderson, that currently Afghanistan has problems in education and health factors as well as infrastructure. This must be improved, if it has been achieved then Peace in Afghanistan will be achieved. (Indonesia's Important Role Keeping Peace In Afghanistan, Embassy of The Republic of Indonesia Kabul, Afghanistan, Report Book., Rachman, 2017).

4) International Crisis Group (ICG) - The US Tink Thank Group which provides input to the World Bank, UN, European Union policies to pressure the International Community to be more involved in resolving the Afghanistan Conflict. The EU and the US are reminded not to enter into international negotiations which lead to function if there is no consensus on all sides in Afghanistan that both are against / can support the Government just to reach peace negotiations. ICG urges all parties to restrain all Rebels' actions and develop consensus on groups in Afghanistan towards a peaceful solution. ICG is also pressing for Pakistan to continue working with the Afghan government rather than with the Taliban rebels.

5) NATO and the United States of America (USA) a) NATO countries, one of which Britain has asked Britain to consider sending another troop to Afghanistan. There are currently 500 British Soldiers in Afghanistan, providing security in Kabul and training for the Afghan Military Academy. This request was made within the last week. NATO Secretary-General Jens Stoltenberg will meet Theresa May on Downing Street on Wednesday $(10 / 05)$ to discuss this matter. This request is as the US has considered increasing its military presence in Afghanistan. (Rachman, 2018)

b) The US is very optimistic that the peace process in Afghanistan will continue. According to information from the CNN News Agency, both US National Security Advisor McMaster and Defense Secretary James Mattis supported the increase in troop numbers. About 3,000 troops will be dispatched to Afghanistan to counter insurgent-related violence. Under the proposals of the Pentagon and the Ministry of Home Affairs, the military's capabilities would be further strengthened to hit the Taliban leader with airstrikes. The plan includes requests from other NATO members for 3,000-3,500 troops, which President Donald Trump has yet to approve of. The Rules of War for US Forces could be increased, with the hope that Donald Trump's Strategy can defeat the Taliban and ISIS. (Rachman, 2018)

c) The Afghanistan Naween Research and Studies Organization (ANSRO). It is suggested that a symposium be formed to bring together all Afghan Stakeholders, including the presence of 
Former Taliban Officials. It is hoped that at this symposium all interests can be brought together to become a solution to realize concrete and independent Peace. ANSRO hopes that the Indonesian Embassy in Kabul can present a figure at the level of the Minister or the Minister of Foreign Affairs himself. (Rachman, 2018)

\section{CONCLUSION}

The Optimistic Path to Peace in Afghanistan has started with Soft-Power Diplomacy in the form of Gathering activities to all Stakeholders through a religious and cultural approach carried out by Indonesian scholars since 7 years ago in Afghanistan and continues through a series of joint meeting activities with the NUA and HPC (Tsolakis, 2017). Besides, of course, not only reports of meetings with the Government of Afghanistan and also meeting with political opponents of the Government, Heads of Foreign Representatives and International Organizations to Community Leaders and Afghan Ulama in the regions. Even so, we realize that we still have shortcomings in not being able to meet directly with Parties who claim to be representatives of the Taliban even though we have met with parties who are the key to the ease of communicating with the Taliban.

Concerning the role of the Ulama/NUA and the HPC, there have been many efforts to immediately realize a "Peace Dialogue" between the two warring parties. But various parties have downplayed the meaning of the roles of both, as if the roles of Ulama and HPC were not yet optimal, even though their main role had been done, namely inviting people to want to remind each other, to invite the truth, to God or not yet running as it should. It is very important to give a warning to a fellow believer. (Youseffi, 2012). Must be patient, charitable, moral, and come to give advice gently and wisdom. This case must not be stopped and all Afghan stakeholders must fully understand this principle matter.

This road is what is meant by the road "Soft-Power Indonesia, together with HPC, NUA and research institutes as well as academics and youth leaders from Afghanistan and internationally through a" Rahmatan Lil Alamin "approach, with 5 Principles, namely: Simplicity, Social Justice, Tolerance, Balance and Participation. Hopefully, the spirit of conducting the Gathering between Ulama, Afghan Stakeholders, or those represented by HPC will continue to provide an optimistic atmosphere, namely "Sharing the Best Practices", goodness in realizing the presence of more concrete peace and friendship between the two countries between human brotherhood towards world peace and the blessings of The God.

\section{ACKNOWLEDGEMENT}

The authors greatly acknowledge the support from Indonesia Defense University Jakarta Indonesia for providing the necessary resources to carry out this research work. The authors are also grateful to the anonymous reviewers and journal editorial board for their many insightful comments, which have significantly improved this article.

\section{REFERENCES}

Bryson J., 1995, Strategic Planning for Public and Nonprofit Organization: A guide to strengthening and sustaining organizational achievement. San Francisco: Jossey-Bass.

Hatta, Mohammad. 1982. Indonesia dan NonAlignment. Jakarta: Bulan Bintang.

Herdiawan, D., \& Ahmadi. 2019. Development strategy of national food sovereignty to encounter radicalism threat. International Journal of Innovative Technology and Exploring Engineering, 8(11), 544-553.

Hettne, Bjorn. 2000. The New Regionalism: A Prologue. In Hettne, B. (ed), The New Regionalism and the Future of Security Development, Vol.4.2000. London: Macmillan.

Hettne, Bjorn., and Fredrik Soderbaun. 2002. Theorizing the Rise of Regions". London: Routledge.

Jay W. Forrester, 1997, Building a System Dynamics Model. Massachusetts: Massachusetts Institute of Technology.

Miere, Christian Lee. 2014. Maritime Diplomacy in the $21^{\text {st }}$ Century: Drivers and Challenges. New York: Routledge.

Moyano I. J. M., E. Rich, S. Conrad, D. F. Andersen, and T. S. Stewart, 2008, "A Behavioral Theory of Insider-Threat Risks: A System Dynamics Approach," Transactions on Modeling and Computer Simulation, vol. 18, no. 2, pp. 72-98. 
Muhammad F., 2014, "Leadership, Governance and Public Policy Implementation Competencies in the Broader Public Sector," European Journal Business and Management, vol. 6, no. 36, pp. 66-74.

Okol Sri Suharyo, Djauhar Manfaat, Haryo D Armono, 2017, Establishing the Location of Naval Base Using Fuzzy MCDM and Covering Technique Methods: A Case Study, International Journal of Operations and Quantitative Management, IJOQM, Vol. 23, Issue 1, pp 61-87.

Rachman, Arief. 2017. Indonesia's Important Role Keeping Peace In Afghanistan, Embassy of The Republic of Indonesia Kabul, Afghanistan, Report Book.

Rachman, Arief. 2018. Towards a Ceasefire Momentum in Kabul Afghanistan, Embassy of The Republic of Indonesia Kabul, Afghanistan, Report Book.

Rachman, Arief. 2018. The Role of Indonesian Ulama In The Process Peace In Afghanistan, Embassy Of The Republic of Indonesia Kabul, Afghanistan, Report Book.

Ruggie, John Gerard. (1993). Multilateralism: The Theory of an Institution, Multilateralism Matters: The Theory and Praxis of an Institutional Norm, ed. John Gerard Ruggie, Columbia, NY: Columbia University Press.

Sandfort J., 1999, "The Structural Impediments to Human Service Collaboration: The Case of Frontline Welfare Reform Implementation," Social Service Review, vol. 73, no. 3, pp. 314-339.
Singh, Uday Bhanu. 2018. Emerging IndiaIndonesia Comprehensive Strategic Partnership. New Delhi: IDSA.

Snyder, Craig A. 2008. Contemporary Security and Strategy. Palgrave: Macmillan.

Sundarakani Balan, Arijit Sikdar, and Sreejith Balasubramanian, 2014, "System Dynamics-based Modeling and Analysis of Greening the Construction Industry Supply Chain," International Journal of Logistics Systems and Management, vol. 18, no. 4, pp. 517-537.

Sterman, J.D., 2000, Business Dynamics Systems Thinking and Modeling for a Complex World. London: Mc Graw Hill.

Thornhill C., 2009, "Local government's contribution to a sustainable developmental state," Administration Publica, vol. 7, no. 3, pp. 24-44.

Tsolakis, N. and J.S. Srai, 2017, A System Dynamics Approach to Food Security through Smallholder Farming in the UK, Chemical Engineering Transactions, vol. 57, pp. 2023-2028.

Youssefi H., 2011, V. S. Nahaei, and J. Nematian, "A New Method for Modeling System Dynamics by Fuzzy Logic: Modeling of Research and Development in the National System of Innovation, "The Journal of Mathematics and Computer Science, vol. 2, no. 1, pp. 88-99. 